\title{
Uma revolução proletária de curta duração e fortíssimo impacto
}

\author{
Lúcio Flávio Rodrigues de Almeida ${ }^{1}$
}

Resumo: Em um aparente paradoxo, numerosas análises marxistas do processo soviético adotaram uma perspectiva personalista. Neste artigo, a inspiração teórico-metodológica é althusseriana, especialmente no que se refere a um conceito não-economicista de modo de produção e à importância dos aparelhos ideológicos. O objetivo é contribuir para uma análise mais objetiva do momento mais profundo (1917-1922) da revolução bolchevique.

Palavras-chave: Proletariado; Luta de classes; Revolução; Processo soviético.

\begin{abstract}
In an apparent paradox, numerous Marxist analyzes of the Soviet process adopted a personalist perspective. In this article, the theoretical-methodological inspiration is Althusserian, especially regarding a non-economistic concept of mode of production and the importance of ideological apparatuses. The aim is to contribute to a more objective analysis of the deeper moment (1917-1922) of the Bolshevik revolution.
\end{abstract}

Keywords: Proletariat; Class struggle; Revolution; Soviet process.

\footnotetext{
${ }^{1}$ Professor do Departamento de Política e do Programa de Estudos Pós-Graduados em Ciências Sociais da PUC-SP; coordenador do Núcleo de Estudos de Ideologias e Lutas Sociais (NEILS); autor de Ideologia nacional e nacionalismo. 2 ed. São Paulo: EDUC, 2014.
} 


\section{Luta de classes e luta política}

Marx e Engels (1988, p. 75) escrevem, em um de seus textos mais célebres, que "toda luta de classes é uma luta política". Apesar do que supõe grande parte dos intérpretes, a afirmação não significa que toda e qualquer luta operária seja política. Não abordaremos aqui, a problemática teórica de Marx anterior a 1845 (Althusser, 2015, p. 25). Tampouco faremos um exame sistemático do uso desses dois conceitos (luta de classes e luta política) na obra posterior. Não se trata, portanto, de uma abordagem sistemática dos recursos ao conceito de classe social em qualquer fase da obra de Marx ou mesmo no próprio Manifesto Comunista, tarefa à qual ainda pretendemos nos dedicar. Nossa escolha, aqui, se deve a três motivos, dois dos quais mais imediatos e outro (o terceiro) de ordem mais teórica: 1) A frase citada acima está no Manifesto Comunista e orienta explicitamente toda a elaboração do mesmo; 2) não por acaso, pois se trata de um texto voltado explicitamente para "a organização do proletariado em classe" capaz de dirigir uma revolução socialista que conduza à construção de uma sociedade sem classes. 3) O momento privilegiado deste processo é fundamentalmente político, o que implica explicitar a posição conceitual que adotamos: a estrutura política é, por um lado, um nível específico e, por outro, o nível crucial onde se refletem e se condensam as contradições de uma formação social (POULANTZAS, 1977, p. 38).

Para diversos críticos de Marx, as lutas e classes se extinguiram ou, pelo menos, não mais ocorrem no núcleo do sistema capitalista, refugiando-se nos países dependentes. Isto merece exame meticuloso, o que não será feito aqui. Apenas observamos que estas críticas ignoram não apenas as diferenças entre os estágios concorrencial e imperialista do capitalismo como entre as fases do imperialismo.

A fase de transição da etapa concorrencial para a imperialista é ininteligível sem a referência a fortes lutas de classes, como as que resultaram em revolução na Rússia e fascismos na Alemanha e na Itália (POULANTZAS, 1978 a, pp. 57-9). Na segunda fase do imperialismo, que se inicia com o final da segunda grande guerra, fortes lutas proletárias em países imperialistas europeus exigiram novas funções do Estado, inclusive com mudança nos padrões de legitimidade que permitissem incursões extraterritoriais na neutralização das lutas de classes, caso, por exemplo, da OTAN e do que viria a ser a União Europeia (POULANTZAS, 1978b, p. 85).

Em relação à segunda crítica, observamos que a expansão do capitalismo produziu um forte processo de transnacionalização deste modo de produção por diversas 
LÚCIO FLÁVIO RODRIGUES DE ALMEIDA $\mathbf{6}$ UMA REVOLUÇÃO PROLETÁRIA (...)

formações sociais que se entrelaçam de diferentes modos com as metropolitanas. Dois grandes ciclos de lutas proletárias que ocorreram na América do Sul - nos anos 196070, no Chile e, nos 1970-80, no Brasil - tiveram seus determinantes fundamentalmente internos, mas se inseriram profundamente em uma teia de determinações internacionais. $\mathrm{Na}$ atual fase do imperialismo, marcada por forte crise econômica, política e ideológica, é, no mínimo, temerário afirmar que as lutas de classes não se intensificarão tanto na área da União Europeia (formações sociais dependentes inclusas), como nos Estados Unidos da América.

Enfim, se na época de Marx o capitalismo estava fundamentalmente restrito a povos considerados brancos (o que não evitava o racismo em relação aos operários), ele, ao se espraiar, inseriu em suas relações básicas povos de diversas etnias (inclusive cor da pele), assim como agigantou os contingentes femininos do proletariado e do subproletariado (e mesmo da burguesia). Isto significa que certas determinações, como as étnicas e de gênero passaram a mais fortemente sobre as relações de classes no contexto do imperialismo ${ }^{2}$.

Não pretendemos, absolutamente, afirmar que os nexos entre estas dimensões estão plenamente elucidados. Apenas destacamos o caráter processual e relacional do proletariado, o que pressupõe uma superação do economicismo que abra caminho para a incorporação das lutas políticas e ideológicas. Isto inclui a referência ao Estado burguês e a destruição e substituição deste por um semi-Estado proletário, bem como à construção de novos aparelhos ideológicos adequados ao exercício de um novo poder político. (ALTHUSSER, 1996; BETTELHEIM, 1976, pp. 223-306; ALMEIDA, 2016, pp. 71-95).

\section{Proletários: entre a reprodução e a ruptura}

Coletivos que se constituem a partir fundamentalmente da posição de produtores diretos no modo de produção capitalista podem ser funcionais para a reprodução deste modo de produção ou, no limite oposto, forças dirigentes de uma revolução anticapitalista. Neste texto, sugerimos, em primeiro lugar, que "trabalhador"/"operário" se refira à dimensão predominantemente funcional dos produtores diretos para a reprodução do capitalismo: e que "proletariado" tenha um sentido politicamente mais abrangente, pois também pode se constituir como um coletivo que atua no sentido revolucionário anticapitalista. Neste sentido, a forte tensão do conceito de proletariado é típica de um

\footnotetext{
${ }^{2}$ Estas questões relacionadas com a permanência e abrangência do conceito de classes sociais são, ao meu ver, abordadas com excessiva condescendência por Balibar (1988).
} 
sujeito que, longe de homogêneo e harmônico, é dotado de contradições internas e cujos processos de constituição se desenvolvem desigualmente.

Após a quase petrificação da teoria política marxista durante o stalinismo, as contribuições desta questão pela corrente althusseriana permanecem valiosas. Também em radical ruptura com o economicismo considera-se o operariado a partir de múltiplas determinações, várias das quais contribuem para sua maior fixação como funcional e outras para o processo de sua constituição como classe revolucionária.

A este respeito, vale a pena retomar, mesmo que rapidamente, alguns avanços fundamentais. O primeiro deles é a tentativa de sistematizar o estudo das fontes dessas determinações, o que passa por um conceito de modo de produção que também não seja economicista. Este, longe de se reduzir a uma única estrutura, a econômica, que circularia por todos pontos do "sistema", é constituído pela sua articulação com a jurídico-política e a ideológica. Tampouco o Estado burguês é pensado como uma instância puramente repressiva. Ao contrário, ele constitui os agentes da produção como indivíduos livres e iguais, o que contribui para bloquear o processo de organização dos trabalhadores diretos como classe distinta e antagônica à burguesia e a ele próprio, o Estado, ou seja, o principal centro de organização da dominação política burguesa. Em outros termos, o complexo processo de constituição do proletariado é visto como indissociável da própria luta política contra o Estado burguês.

Também a estrutura ideológica exerce um papel no sentido de interpelar os trabalhadores diretos (para ficarmos neste caso) enquanto, por exemplo, adeptos desta ou daquela religião, dotados de certos vínculos familiares, adeptos de um clube esportivo, sexuados, pertencentes a uma etnia, cidadãos, contribuintes etc. Em suma, produz-se um jogo de interpelações que contribuem, no fundamental, para reforçar a reprodução das relações de exploração e dominação de classe (THERBORN, 1996). Se levarmos em conta as formações sociais, com sua complexa articulação de modos de produção, este repertório de interpelações, ao operar em uma teia mais multifacetada de relações sociais, fica bem mais intrincado.

Cremos que, no geral, estas observações preliminares são suficientes para superar uma concepção demasiado simples (em geral, economicista) das relações entre classe e organização política ${ }^{3}$. Mas se abre uma questão que, também longe de examinar em profundidade, somente mencionarei para expressar a posição que adoto.

\footnotetext{
${ }^{3}$ A começar pelo caráter singular ou plural desta organização.
} 
Por um lado, muitos marxistas parecem ignorar que o capitalismo se reproduz e veem o sistema sempre à beira de uma revolução. Neste sentido, não apenas desconsideram que, historicamente, a dominância deste modo de produção se expande há cerca três séculos; mas também, no plano teórico, que a mais importante obra de Marx, O Capital contempla amplamente do ponto de vista da reprodução a estrutura econômica deste modo de produção ${ }^{4}$.

Como vimos, o proletariado é, em ampla medida, funcional para a burguesia, o que possibilita que o modo de produção capitalista se reproduza.

Neste sentido, "uma teoria política comunista deveria refletir sobre o nexo reproduçãorevolução, sobre a transformação da luta operária em luta revolucionária" (PORCARO, 200, p. 76). Tal esforço deveria levar em conta a contradição interna ao fim, ao objetivo, da luta comunista que emerge no processo de reprodução", numa dinâmica que exige, por si só, uma constante reavaliação "das relações de forças 'atuais' entre as classes". Estamos longe de um processo linear ${ }^{5}$.

Esta dupla e contraditória dimensão já havia sido levada em conta, com imensa maestria, por Marx (s/d), ao redigir a mensagem inaugural da Associação Internacional dos Trabalhadores (A. I. T), em 1864, após a derrota da onda revolucionária de 1848; pelos bolcheviques ao se recusarem a acompanhar a maré nacional-belicista que tomou conta também da classe operária às vésperas e na primeira fase da I Guerra Mundial; e , em março-abril de 1917, por Lenin (s/d; 1917), ao perceber a nova correlação de forças que se constituiu na Rússia após a revolução de fevereiro/março.

Se o escrito acima faz sentido, é necessário retomar a dupla e contraditória dimensão de proletariado. Como despojado da posse e da propriedade dos meios de produção, embora constituído, nos planos jurídico-político e ideológico, como indivíduo livre e igual aos demais, o que o torna, neste âmbito, igual ao burguês, tornando-se ambos cidadãos civis ${ }^{6}$. E enquanto coletivo organizado política e ideologicamente em uma determinada luta contra a dominação burguesa. Aqui se trata de uma contradição real que

\footnotetext{
${ }^{4} \mathrm{O}$ que implicou considerar a presença indireta, no econômico, dos efeitos de outras estruturas e levar em conta o caráter potencialmente antagonístico presente na determinações por este todo complexo com dominância.

${ }^{5}$ Não somente fazemos uma interpretação um tanto livre das teses de Porcaro como é preciso levar em conta que o autor, ao relançar seu artigo dezessete anos depois, acrescentou um pos-scriptum carregado de autocríticas (id., pp. 78-81).

${ }^{6}$ Ficam em aberto, pois dependentes da correlação de forças, as conquistas das cidadanias política e social. A este respeito, Saes (1998; pp. 15-50).
} 
não se reduz ao plano das ideias nem se resolve pelo simples desenvolvimento das forças produtivas nem pela vontade de uma direção. Esta contradição atravessa as próprias relações entre partido(s) operário(s)/proletário(s) e demais subaparelhos ideológicos no contexto de avanços das lutas dos produtores diretos, de suas relações com outras classes, com o Estado burguês. Enfim, nos processos de tentativas de transição, essa contradição também atravessa os dispositivos de exercício de poder político pelo proletariado.

Em outros termos, o processo de constituição do proletariado em classe é sinuoso, relacional, contraditório e desigualmente desenvolvido, o que se aplica inclusive a períodos revolucionários.

\section{O processo soviético}

Longe de serem frutos de formulações abstratas elaboradas por intelectuais contemporâneos, estas questões estiveram presentes já no início do processo revolucionário de outubro de 1917 e foram vividas de modo dramático e decisivo até meados dos anos 1920.

Comecemos por três aspectos que já se destacaram na Revolução de 1905. O primeiro foi a extraordinária capacidade de luta de um proletariado que, mesmo diante da mortandade produzida pelo czarismo, insistia em se manter de pé e parecia renascer das cinzas. Repressão que - e este é o segundo aspecto - era feita por um Estado fortemente marcado por uma série de características pré-capitalistas, o que assinalava, desde então, a extrema complexidade das revoluções que marcaram o século XX. Enfim, o uso da palavra "proletariado", aqui, está longe de ser casual: de fato estas lutas produziram um salto no patamar organizativo dos trabalhadores diretos com a criação dos sovietes - conselhos de operários fabris - que se propagariam entre soldados e camponeses. A Revolução de 1905 produziu uma forma de organização que expressava grande avanço político no processo de constituição do proletariado como classe e, mesmo na ausência de um programa revolucionário bem definido e (o que é importantíssimo) redefinido segundo as mudanças das lutas de classes, significava que aquelas relações predominantemente funcionais entre os trabalhadores diretos e os proprietários dos meios de produção estavam em vias de serem superadas.

Nove anos mais tarde, quando eclodiu a Grande Guerra, no interior do Império Czarista, a exemplo do que ocorreria em praticamente toda a Europa, os agrupamentos políticos influenciados pelo marxismo aderiram aos "seus" respectivos Estados, com 
uma importante exceção: os bolcheviques, fração do Partido Socialdemocrata Russo, contrariamente aos mencheviques, adotarem, depois de muito debate (BROUÉ, 1972, pp. 106-110), o programa de transformar a guerra imperialista em uma guerra civil revolucionária. Embora numericamente insignificantes, os bolcheviques estavam muito bem preparados para o que se propunham e atuavam em um terreno privilegiado: a ausência, no moribundo Império Czarista, de consolidados aparelhos (repressivo e ideológicos) de reprodução do poder burguês ${ }^{7}$ e a presença de dispositivos que reproduziam a memória de uma forte insurreição proletária que fora vencida, porém não desqualificada.

Isto não significa que o programa dos bolcheviques em relação ao Império Czarista fosse o de uma imediata revolução socialista. Ali se tratava de uma etapa democráticaburguesa - dirigida pelo proletariado -, a qual criaria as condições, especialmente um contexto marcado pela revolução socialista internacional (com eixo no Ocidente Europeu) para uma nova etapa revolucionária. Todavia, em contrapartida ao forte nacionalismo que se espraiou pelo que se esperava que fosse o epicentro da revolução, nesse Império a surpresa foi mais favorável: forte insurreição operária e popular, com a retomada da presença, em maiores dimensões, dos sovietes. A etapa democrático-burguesa foi rapidamente superada e se produziu uma crise revolucionária na qual os sovietes se recompuseram de modo muito mais amplo e, em uma conjuntura bem mais complexa, se confrontavam objetivamente com as forças que dirigiam o processo de constituição do Estado no bojo da revolução burguesa.

Em abril de 1917, Lenin defendeu, para surpresa geral, inclusive dos bolcheviques, a tese de que havia na Rússia um duplo poder: o que se materializava no aparelho institucional de Estado e o dos sovietes. Ora, a comanda "Todo o poder aos sovietes" implicava, de certo modo, a premissa de que o proletariado avançava no sentido de conquistar o poder político. Ou seja, tornava-se um adversário à altura do Estado burguês e capaz de organizar um novo poder político de classe. A rigor, como observa Bettelheim (1976, p. 111), esta possiblidade estava contemplada desde julho de

\footnotetext{
${ }^{7}$ Neste sentido, as interpretações convencionais de uma célebre passagem de Gramsci, ("no Oriente, o Estado era tudo, a sociedade civil era primitiva e gelatinosa...") merecem relativização. Consideram que o Estado burguês estava consolidado e que a sociedade civil é, em princípio, "neutra", ou seja, que o o seu conceito não se refere, naquele texto, à hegemonia/ausência de hegemonia burguesa. Em outros termos, ignoram que, ao longo de 1917, o próprio avanço das lutas proletárias e populares também no plano ideológico - o que se expressa na atuação partidos, jornais, correntes de opinião etc. - travou o processo de constituição dessa hegemonia burguesa. Agradecemos a Marcos del Roio, da UNESP-Marília, o qual não é responsável pelos eventuais equívocos aqui cometidos, a troca de ideias que tivemos sobre Gramsci e o processo soviético.
} 
LÚCIO FLÁVIO RODRIGUES DE ALMEIDA 6 UMA REVOLUÇÃO PROLETÁRIA (...)

1905, com a publicação, por Lenin, de As duas táticas da socialdemocracia na revolução democrática, o que não evitou um surto de hesitação entre os bolcheviques. Mas, em um processo marcado por intensos debates internos, apostaram na capacidade de direção proletária do campesinato com vistas à nova etapa da revolução.

Em uma situação totalmente nova, a começar pela presença aberta e ativa, em plena guerra, de inúmeras correntes políticas de esquerda, o partido bolchevique demonstrouse capaz de atualizar sua linha política e sinalizar meios concretos de resolver a crise em favor da revolução e não do esmagamento desta por forças internas e externas ao território do Império recém-extinto. Em seu opúsculo O Estado e a Revolução, escrito, na clandestinidade, em agosto-setembro de 1917, Lenin referiu-se à observação de Engels sobre o cuidado da burguesia francesa em desarmar os operários após cada revolução. E, logo em seguida, alertou que, ao discursar em 9 de junho do mesmo ano, o menchevique Tseretelli cometeu "a imprudência de anunciar" e aprovar como uma "necessidade 'política' em geral" a decisão da burguesia de desarmar os operários de Petrogrado" (LENIN, 2007, p. 92) . $^{8}$

Ao longo de 1917, os bolcheviques não tiveram peso na primeira revolução, que, aliás, ninguém previu, (BROUÉ, 1972, p.114), não criaram os sovietes nem foram os responsáveis exclusivos pelo aprofundamento da uma crise revolucionária. Mas seinseriram nesta de um modo original, conquistaram a maioria entre os sovietes e, apesar da presença praticamente nula no campo, onde vivia 80\% da população (ANDERSON ,2010, p.61), desbloquearam a aliança com o campesinato pobre e médio. Em suma, desempenharam um importantíssimo papel no aprofundamento - em vez da extinção cruenta - daquela crise, contribuindo para o avanço do processo de constituição do proletariado como classe. Como observou Althusser (2015, p. 76), a Rússia estava "grávida de duas revoluções". Uma "burguesa em atraso na véspera de uma revolução proletária". Daí a incapacidade, "mesmo adiando uma, de conter a outra". Lenin percebeu "nessa situação sem saída (para as classes dirigentes), as condições objetivas" e o partido bolchevique foi constitutivo das "condições subjetivas (...) contra este elo fraco da corrente imperialista". Mostrou-se que, em condições objetivas determinadas, a derrocada do poder político burguês por uma revolução proletária, tal como Marx e Engels havia teorizado em termos bastante gerais no segundo capítulo do Manifesto do Partido Comunista, podia se realizar.

\footnotetext{
${ }^{8}$ Tseretelli liderava o bloco constituído pelos menchevique e socialistas revolucionários (id., ibid.). A respeito do risco de massacre do movimento operário e popular pelo governo provisório, ver a arguta análise feita por Mandel (1917).
} 
Esta complexa e contraditória relação entre o funcional e o revolucionário não se restringe ao plano das ideias, nem mesmo das "visões de mundo". Materializam-se como práticas que se constituem e reproduzem de modo ampliado (ou involuem e se extinguem) no interior de aparelhos ideológicos. Uma compreensão mais profunda do processo soviético deve passar pelo exame acurado das relações entre o aparelho estatal em fase de constituição (e decomposição) durante o breve período da revolução democráticoburguesa; os sovietes que se reconstituem de modo mais amplo e profundo ao longo de 1917; e o partido bolchevique ${ }^{9}$. Nos três casos, o processo teve marchas e contramarchas, especialmente com as Jornadas de Julho, que desembocaram em aparente consolidação do aparelho estatal, séria derrota dos bolcheviques e maior ainda dos sovietes. Mas, no final de agosto, após o fracasso do golpe de Kornilov, a retomada da ascensão política dos sovietes, em sincronia com seu processo de bolchevização, abriria o caminho para a tomada do poder em 25-26 de outubro (TROTSKY, 2007, pp.729-31;1016-1037; REIS FILHO, 1996, p.69).

Com o partido bolchevique, os sovietes (inclusive de soldados e camponeses) e, principalmente, as massas operárias em ligação direta com o primeiro, a derrubada de um poder político burguês ainda não consolidado ocorreu com relativa facilidade ${ }^{10}$. A insurreição foi o ponto culminante de um processo revolucionário considerado por seus principais dirigentes apenas o primeiro momento de uma revolução internacional.

Isto não deve obscurecer as sérias limitações do partido bolchevique. Já vimos que era frágil junto ao campesinato. E, como, observa Bettelheim (1986, pp. 89-90), mesmo em relação à classe operária, o papel ideológico que exerceu foi mais premido pelas injunções políticas da conjuntura: predominaram os "interesses imediatos" sobre o envolvimento com "propostas embasadas em um conhecimento profundo das estruturas sociais e de como transformá-las". Não por acaso, Lenin, em suas Teses de Abril, deixou claro que "nossa tarefa imediata não [era] 'introduzir' o socialismo, mas apenas passar imediatamente ao controle da produção social e da repartição dos produtos pelos sovietes de deputados e operários". (LÊNIN: s/d: 1917, apud BETTELHEIM, 1976, p. 90).

\footnotetext{
${ }^{9}$ A rigor, seria preciso examinar também os demais partidos e organizações existentes no período, além de outros aparelhos ideológicos, como, por exemplo, a Igreja Ortodoxa, a Guarda Vermelha (ligada aos bolcheviques) e, o mir, já em acentuado processo de desagregação e que, como observa Bettelheim (1976:193), funcionava como um aparelho político-ideológico dos camponeses abastados.

${ }^{10}$ A respeito da tomada de Petrogrado e do Palácio de Inverno em Petrogrado, principal centro da Revolução de Outubro, cheia de trapalhadas militares, mas politicamente bem-sucedida e incruenta, ver a exposição ao mesmo tempo irônica, crítica e calorosa feita por Trotsky, (2007, caps. 43-6).
} 
O processo revolucionário logo se deparou com sérios obstáculos, alguns dos quais foram enfrentados com muita ousadia e criatividade. Mas, no seu conjunto, eram intransponíveis, dada a correlação concreta de forças, inclusive no plano teóricoideológico. Mencionemos rapidamente dois obstáculos fundamentais: 1) ao contrário do que previam os bolcheviques, a revolução foi derrotada no plano internacional (leiase, em termos imediatos, "europeu"; 2) esta derrota favoreceu terrivelmente o cerco e a intervenção de Estados estrangeiros, além da guerra civil.

A partir de então, os impactos da guerra imperialista se fizeram valer contra o proletariado e os aparelhos de que dispunha, tanto os criados por iniciativa direta (os sovietes) como aquele ao qual se "fundiu" (o partido bolchevique) ${ }^{11}$. A força desses impactos produziu um extraordinário rebaixamento das possibilidades revolucionárias.

Por um lado, não faltou extraordinária e diversificada inventividade cultural que se voltasse para a revolucionarização dos mais diversos aparelhos ideológicos. Mencionemos apenas o construtivismo no relativo à arquitetura e ao urbanismo. Kopp (1990, p.76) observa que o "'conceito de modo de vida', de 'reconstrução do mundo', como se dizia na época [foi] a base da maior parte das pesquisas dos anos vinte", com objetivos que iam além "do estrito domínio da arte". No final da década, em Moscou e "alguns centros industriais", surgiram "residências-comunitárias, clubes operários, cozinhas-fábrica e outros edifícios, que testemunhavam ao mesmo tempo uma reviravolta na arquitetura" com vistas a "introduzir o novo modo de vida na realidade soviética" (id., p.106). Durou pouco, mas houve um período em que, consoante a advertência de Maiakovski, o construtivismo tomou cuidado para não se tornar "outra escolha estética", chegando, inclusive a se envolver em um riquíssimo debate sobre o que seria um espaço urbano mais adequado a um processo revolucionário que, longe de se restringir à transformação das relações e produção, afetaria o conjunto das relações sociais (id., 91; passim).

Mas o impulso deste e de outros movimentos de transformação do modo de vida não contou com a adesão da esmagadora maior parte do campesinato nem da "imensa maioria das outras camadas sociais" (Id., p. 87). Tampouco se integrou a um profundo processo de revolucionarização de amplos contingentes do proletariado. No campo e na cidade, as amplas massas gastavam suas energias na busca da sobrevivência (KOPP, 1979, p.76). Procura nada fácil se considerarmos os obstáculos já mencionados.

Em 1919, Lenin, no VII Congresso do Partido Comunista (b)R, alertou para três questões imediatas e candentes: a fome o abastecimento e o ... piolho:

\footnotetext{
${ }^{11}$ Não mencionemos o Estado-comuna, que não saiu do plano das intenções.
} 
Nosso terceiro problema é a luta contra os piolhos, contra os piolhos que transmitem o tifo. Tifo, em uma população que está esgotada pela fome, está doente, não tem pão, sabão ou combustível, pode gerar uma calamidade que impedirá nossa luta contra qualquer tipo de desenvolvimento socialista. Este é o primeiro passo em nossa luta pela cultura e, também, é uma luta pela existência. (LENIN, 2002;1919)

Tarefas urgentes não faltavam e o pessoal em condições de realizá-las não era tão numeroso assim. Daí a frequência das mobilizações de "tudo" e de "todos" para a realização de tarefas prementes: “"Tudo pelo abastecimento! ', 'Tudo pelas colheitas!', 'Tudo pelo combustível!', ‘Tudo pelos transportes!' (...) ‘Todos contra Koltchak!', ‘Todos contra Deninkine!'”. (LINHART, 1977, p.17).

Não havia tantos assim e o modo como foram mobilizados contribuiu para uma série de problemas que degradaram ainda mais o mundo industrial, seja quanto ao aspecto físico, seja no tocante às relações sociais, inclusive ao número e à composição do proletariado. A rápida mobilização do maior empenho de "todos" incidiu fundamentalmente sobre os proletários mais aguerridos e mais criativos, o que, por si só, contribuiu para deprimir estas características no conjunto dos restantes.

Como observa Bettelheim (1976:158), “o proletariado russo (...) foi literalmente desintegrado durante os anos da guerra civil, e continuou desintegrando-se no início da NEP"12. Em 1922, havia apenas 4,6 milhões de operários empregados, (2 milhões nas atividades industriais), no lugar dos 11 milhões que existiam em 1913. E a composição se alterou profundamente. Muitos dos mais combativos morreram nas diversas frente de luta; outros se deslocaram para "os aparelhos do partido, dos sindicados e do Estado". Além dos que, "nos grandes centros industriais", simplesmente abandonaram as fileiras da classe operária, devido ao desemprego ou à crise alimentar, retornando aos seus povoados de origem". Na contramão, pessoas “de origem burguesa e pequeno-burguesa, geralmente hostis à ditadura do proletariado, penetraram nas fileiras da classe operária para se beneficiarem das rações dos trabalhadores manuais ou para tentarem ocultar sua origem de classe" (id., ibid.).

Na medida em que a questão do abastecimento se tornou vital, a tendência ao produtivismo se fortaleceu e se sobrepôs às que enfatizavam processos de politização. Para se produzir mais, intensificaram-se padrões autoritários, com a separação de tarefas

\footnotetext{
${ }^{12}$ Carr (1966, p.196) observa que, já no VII Congresso do Partido, em março de 1918, Bukharin falou sobre a "desintegração do proletariado". O mesmo autor faz um impressionante balanço da degradação do mundo industrial russo durante o período do Comunismo de Guerra (Carr, 1966, pp. 176-229).
} 
direção (cada vez mais centralizadas) e de execução, o que implica sérias dificuldades para a transformações de aparelhos ideológico (inclusive os entranhados no universo fabril) em lugares cruciais para o processo de transição.

A questão se tornou ainda mais complexa com a militarização do trabalho e, em um processo que se reforça com o final da NEP, de inserção de contingentes oriundos do ex-campesinato rico (kulaks expropriados) na indústria. Numa espécie de inversão perversa, a condição operária tornou-se, em diversas situações, objeto de desconfiança e desprezo (LINHART, 1977, p. 177).

Os quadros comunistas eram minoritários no interior de um aparelho de Estado que não parava de crescer e funcionava com grande autonomia em relação aos que pretendiam que ele se prestasse ao exercício de um poder político de um proletariado em refluxo. Lideraram uma revolução, mas, para deslancharem, precisariam realizar "uma obra inteiramente nova" que seria "incrivelmente difícil" se "os camaradas operários dos países mais desenvolvidos do ponto de vista capitalista não [os] ajudassem rapidamente" (LENIN, 1980;1922, p.575).

Nas condições difíceis em que se encontravam, era outro o "totalmente novo" que surgia e sobre qual ninguém tinha escrito uma só linha: o capitalismo de Estado sob um poder proletário (Id., p. 582). Diante deste, o Estado assemelhava-se a um carro que

não vai para onde o dirigem, mas para onde o dirige alguém, algo de ilegal, algo de ilegítimo, sabe Deus de onde veio, talvez os especuladores, talvez os capitalistas privados, ou talvez uns e outros (...) Isto é o essencial que é preciso recordar quanto à questão do capitalismo de Estado (Id., p. 581-2).

E, contra a insistência de diversos membros do partido em organizarem de modo unitarista, e não federativo, com nítida predominância da Rússia, as diversas nacionalidades menores, Lenin advertia, em texto ditado para suas secretárias, que o Estado saído da Revolução de Outubro ainda estava longe de ser socialista. Era o mesmo "velho aparelho da Rússia, o qual (...) nós emprestamos ao tsarismo e mal começamos a engraxar" (LENIN, 2017; 1922).

Talvez seja o momento de observar que, também “embaixo", havia um "totalmente novo" cuja abordagem não pode se restringir à dimensão prática: quais lutas desenvolver, nas condições concretas do início do processo revolucionário soviético, no interior e a partir do espaço produtivo de modo, de modo a que este se tornasse menos adverso à reconstituição de um proletariado revolucionário? 
Com a inserção do partido comunista em um sistema de aparelhos (repressivo e ideológicos) de Estado, ou seja, cada vez mais imbricado nas relações de separação entre os trabalhadores diretos e os meios de produção, não havia lugar para os sovietes ou aparelhos ideológicos similares. Cresceu o descompasso entre um partido revolucionário e um proletariado que, se tornaria, no dizer de Linhart, (1977, p. 165), inencontrável.

O próprio Lenin, com seu apurado senso prático e inquietação teórica, atribuía cada vez menos, ao longo deste processo, à maioria daqueles trabalhadores a condição de revolucionários. Ao criticar, em 30 de dezembro de 1922, os que, em nome do internacionalismo, defendiam, na prática, a subordinação das nacionalidades menores à Rússia ${ }^{13}$, alertava para o risco incontornável de que "a insignificante percentagem de operários soviéticos e sovietizados [afundasse] nesse mar de imundície chauvinista russa como a mosca no leite" (Lenin, 2017; 1923). Ou seja, nem todos eram sovietizados. O processo de constituição do proletariado em classe encontrava sérios problemas para se reproduzir.

A revolução bolchevique realizada na perspectiva de contar com a ajuda da revolução nos países capitalistas desenvolvidos, logo se viu enredada internacionalmente em uma fortíssima onda contrarrevolucionária. Nestas condições, ao invés de se completar a destruição, reforçaram-se objetivamente as estruturas de um aparelho estatal que se demonstrou eficaz para vencer as intervenções externas e, especialmente, a guerra civil. A partir de 1928, em um outro contexto, com a implementação dos Planos Quinquenais, desenvolveu-se rapidamente a industrialização, o que foi decisivo para que a URSS enfrentasse o principal peso da Segunda Grande Guerra. Porém não se criaram, muito pelo contrário, avanços consideráveis no controle proletário da produção e na constituição de novos aparelhos de poder político, inclusive no plano (semi)estatal.

Isto não deve servir para obscurecer o efetivo entrelaçamento de proletários e bolcheviques. No início de 1917, o partido contava com 24 mil membros. Saltou para 612 mil em março de 1920 e 732 mil no mesmo mês do ano seguinte. Apesar do forte número de depurações, pois muitos dos que ingressavam não tinham a formação políticoideológica requerida, em 1923 eram cerca de meio milhão. Dentro do partido, o número de operários era de 14 mil em 1917. Saltou para 270 mil em 1920 e 300 mil em 1921. Também participaram em números consideráveis dos aparelhos estatais, inclusive no

\footnotetext{
${ }^{13}$ Aqui não temos tempo nem espaço para me abordar mesmo um problema crucial do processo de formação da URSS. A este respeito, sugerimos, além da consulta ao texto de Lenin publicado neste dossiê, a leitura do capítulo “Autonomia versus Federação" (1922-3) de Lenin (2007, pp. 33-47).
} 
Exército Vermelho" (BETTELHEIM, 1976, pp. 176-7). Neste sentido, ocorreu um entrelaçamento de partido e classe, com uma extraordinária energia política que, apesar da dificuldade de transformação do aparelho estatal e da impossibilidade de produção de fortes aparelhos ideológicos proletários, possibilitou a construção de um poder proletário até um pouco depois da guerra civil, no final de 1920 (Id., 176-8).

Mas o impacto da Revolução de Outubro foi muito maior, tanto no plano interno como no internacional. Mobilizou corações e mentes. Miríades de práticas estruturadas em aparelhos ideológicos, especialmente partidários e sindicais se expandiram, de modo desigual por todo o planeta, servindo de impulso a múltiplos tipos de lutas proletárias e populares. Em diversos países, um modo de vida proletário imprimiu marcas profundas ao conjunto das relações sociais (dimensões culturais inclusas), embora não fosse capaz de revolucioná-las. Lutas de libertação nacional, várias delas dotadas de forte potencial anti-imperialista (ou seja, contra o capitalismo em seu período monopolista) encontraram apoio material e fonte de inspiração na existência da URSS. Tal situação perdurou até meados dos anos 1970, embora, desde o final dos 50, o prestígio da URSS tenha sofrido sucessivos abalos e esta deixasse de inspirar grande parte dos movimentos revolucionários socialistas.

Dadas as condições extremamente desfavoráveis em que ocorreu, o que impressiona é o quanto o processo soviético contribuiu para o desenvolvimento das lutas proletárias, operárias, populares e de libertação nacional em todo o mundo. Que, neste centenário, o exame crítico também contribua para, em um novo contexto, revitalizar as forças capazes de unificar as lutas para mudar a vida. 


\section{Referências Bibliográficas}

ALTHUSSER, Louis (2015). Por Marx. Campinas: UNICAMP.

(1996). Ideologia e aparelhos ideológicos de Estado (notas para uma investigação). In: ZIZEK, Slavoj. (1996)). Um mapa da ideologia. Rio de Janeiro: Contraponto.

ALMEIDA, Lúcio F. (2016). Ideologia, ideologias, lutas de classes: Althusser e os aparelhos ideológicos (de Estado). Marília: Oficina Universitária; São Paulo; Cultura Acadêmica.

ANDERSON, Perry. (2010). Two Revolutions: Rough Notes. Disponível em: Dhttp:// content.csbs.utah.edu/ mli/Economies\%205430-6430/Anderson-NLR29504\%5b1\%5d. pdf Acesso em: 12/03/2017.

BALIBAR, Etenne (1988). De la lutte de classes à la lutte sans classes? In: BALIBAR, E e WALLERSTEIN, Immanuel Race, nation, classes: les identités ambiguës. Paris: La Déoouverte.

BETTELHEIM, Charles. (1976). As lutas de classes na União Soviética. V. I. Rio de Janeiro: Paz e Terra.

BROUÉ, Pierre. (1972). Es Partido Bolchevique. Vol. 1. São Paulo: Sundermann.

CARR, Edward H. (1966). The Bolshevik Revolution: 1917-1923. London: Pelican Books,v. 2.

GRAMSCI, Antonio (2000). Caderno 7 (1930-31). In: Cadernos do cárcere. V. 3 Maquiavel: notas sobre o Estado e a política. Rio de Janeiro: Civilização Brasileira.

KOPP, Anatole. (1979). “Toute une Amérique de locomotives...” Entrevue avec Anatole Kopp sur la URSS des années 1920. Communisme, n. 3.

LEWIN, Moshe. (2007). O século soviético. Rio de Janeiro; São Paulo: Record.

LENIN, Vladimir. (s/d: 1902). Que fazer?. https://www.marxists.org/portugues/ lenin/1902/quefazer/index.htm. Consulta em 14/03/2017.

. (s/d; 1917). Sobre as tarefas do proletariado na presente revolução. https:// www.marxists.org/portugues/lenin/1917/04/04_teses.htm. Consulta em 16/02/2017.

.(2002;1919). Eight All-Russia Conference of The R.C.P.(B). https://www. marxists.org/archive/lenin/works/1919/dec/02.htm. Acesso em 15/05/2016).

. (2007). O Estado e a Revolução. São Paulo: Expressão Popular.

"autonomização".

.(2017; 1922). Para a questão das nacionalidades ou da

LINHART, Robert (1977). Lenine, os camponeses e Taylor: a organização econômica soviética e o partido bolchevista. Lisboa: Iniciativas Editoriais. 
LÚCIO FLÁVIO RODRIGUES DE ALMEIDA $\mathbf{6}$ UMA REVOLUÇÃO PROLETÁRIA (...)

MANDEL, David. (1917). The historical legacy of the October Revolution. Ponto-evírgula, n.21.

MARX, Karl. (s/d; 1864). Mensagem inaugural da Associação Internacional dos Trabalhadores.https://www.marxists.org/portugues/marx/1864/10/2//7.htm. Consulta em $16 / 03 / 2017$.

MARX, Karl e ENGELS, Friedrich. (1988). Manifesto do Partido Comunista. Rio de Janeiro/São Paulo: Contraponto/Perseu Abramo.

(s/d). Manifest der Kommunistischen Partei. https://www.marxists.org/ deutsch/archiv/marx-engels/1848/manifest/. Consulta em 23/02/2015.

PORCARO, Mimmo. (2001). Charles Bettelheim: um longo adeus. Outubro, n. 5.

POULANTZAS, Nicos. (1977). Poder político e classes sociais. São Paulo: Martins Fontes.

(1978a). Fascismo e ditadura. São Paulo: Martins Fontes.

(1978b). As classes sociais no capitalismo de hoje. 2 ed. Rio de Janeiro:

Zahar.

(1986). Poder politico e classes sociais. São Paulo: Martins Fontes.

REIS FILHO, Daniel A. (1996). Uma revolução perdida. São Paulo: Perseu Abramo.

SAES, Décio (1998) O conceito de Estado burguês. In: Estado e democracia: ensaios teóricos. 2 ed. Campinas: ÚNICAMP.

THERBORN, Göran, (1996). A formação ideológica dos sujeitos humanos. Lutas Sociais, 1.

TROTSKY, Leon. (2007). História da Revolução Russa. V. 2. São Paulo: Sundermann. 